\title{
In Silico Insight the Prediction of Chlorogenic Acid in Coffee through Cyclooxygenase-2 (COX2) Interaction
}

\author{
YOHANES BARE ${ }^{1 *}$, DEWI RATIH TIRTO SARI ${ }^{2}$, YOGA TRIBAKTI RAHCMAD ${ }^{3}$, \\ AGUSTINA ELIZABETH ${ }^{4}$, GABRIELLA CANDRAKIRANA KRISNAMURTI ${ }^{5}$, ANDRI \\ MAULIDI $^{6}$ \\ ${ }^{1}$ Biology Education Study Program, Faculty of Teaching and Training, Nusa Nipa University \\ J1. Kesehatan No. 3 Beru, Alok Tim, Maumere, East Nusa Tenggara, Indonesia. 86111 \\ *Email: bareyohanes@gmail.com \\ ${ }^{2}$ Department of Biology, Faculty of Mathematics and Natural science, Brawijaya University \\ Jl. Veteran Malang, Ketawanggede, Malang, Jawa Timur. Indonesia. 65145 \\ ${ }^{3}$ Research Group of Sekolah Progresif Bumi Shalawat \\ Jl. Kyai Dasuki No.1, Lebo, Sidoarjo, East Java. Indonesia. 61223 \\ ${ }^{4}$ Physics Education Study Program, Faculty of Teaching and Training, Nusa Nipa University \\ Jl. Kesehatan No. 3 Beru, Alok Tim, Maumere, East Nusa Tenggara, Indonesia. 86111 \\ ${ }^{5}$ Biotechnology Program, School of Bioresources and Technology, \\ King Mongkut's University of Technology Thonburi \\ 126 Pracha Uthit Rd, Bang Mot, Thung Khru, Bangkok, Thailand. 10140 \\ ${ }^{6}$ Department of Biology, Faculty of Mathematics and Natural Science, Palangka Raya University \\ Jl. Yos Sudarso, Palangka, Kec. Jekan Raya, Kota Palangka Raya, Central Kalimantan. 74874
}

Received 04 August 2019; Received in revised form 04 September 2019;

Accepted 01 December 2019; Available online 30 December 2019

\begin{abstract}
Inflammation was signs of pathological or abnormality in tissue to give an alert as a trouble signal to the system. Therapeutic using NSAIDs has some side effects. This research explored the potential role of chlorogenic acid as natural therapeutic compound to inhibit the inflammation target such as COX-2 by interaction model. The research method used in the study by molecular docking approach, which binds ligand and protein. Protein data provided by Protein Data Bank (ID: 6cox) while, chlorogenic acid obtain from PubChem (CID: 1794427). We docked COX-2 and chlorogenic acid using Hex 8.0.0. Visualization and analysis of the molecular interactions of chlorogenic acid and COX-2 conducted by the Discovery Studio Client 4.1 software. Chlorogenic acid has high permeability and is easily absorbed based on five Lipinski Rule. Interestingly, we found Fifteen amino acid was binding with chlorogenic acid that formed by hydrogen bond and van der Waals. The interaction between ligand-protein results in energy binding$327.59 \mathrm{cal} / \mathrm{mol}$. Chlorogenic acid has a potential role to inhibit inflammation pathway by inhibiting COX2. We predicted chlorogenic acid has a potential as therapy anti-inflammatory to suppress COX-2 as mediator inflammation.
\end{abstract}

Keywords: amino acid; anti-inflammatory; chlorogenic acid; inflammation; in silico, COX-2

\section{INTRODUCTION}

Inflammation is a physiological response to abnormal conditions in the body. Inflammation can occur locally, systemically, acutely and chronically, causing severe pathological abnormalities (Abdulkhaleq et al., 2018; Phalitakul et al., 2011). When inflammation occurs, the body will respond by forming anti-inflammatory cytokines to produce symptoms of inflammation. Bare et al., (2018) in the previous study reported the protein profile of all tissues in inflammation (type 2 diabetes mellitus) group and the normal group was completely diverse as proper by Experion Pro260 analysis besides in SDSPAGE analysis show same results.

Inflammation, which happened in human's body correlated with the mediator inflammation such as Cyclooxygenase-2 (COX-2). COX-2 has a function of initiation and maintenance during inflammation abnormal physiological conditions. These Cyclooxygenase-2 regulations by stimulating the production of prostacyclin (PGI2), also preventing platelet aggregation (Al-Saeed, 2011; Knights et al., 2010). In another study to developed COX-2 
inhibitor as known as NSAID is aspirin, acetylsalicylic acid. Aspirin binds to the COX active site and has a higher affinity to Ser-530 (Smith \& Murphy, 2016).

To therapeutic inflammation in human's body, most people use drugs such as use nonsteroidal anti-inflammatory drugs (NSAIDs). The drug treatment not only in fever and mild pain but also to act by reducing chronic inflammatory (Bäck et al., 2012). The function of NSAIDs inhibition of COX-2 (possibly by blocking PGI2 biosynthesis while not hindering TXA2 formation (Phalitakul et al., 2011).

Overconsumption of NSAIDs drugs has some sides effect such as gastrointestinal, cardiovascular risks (Al-Saeed, 2011), adrenal atrophy (Phalitakul et al., 2011), and induce the risk of atrial fibrillation (Bäck et al., 2012). Due to the side effects of the NSAIDs, researchers concern to find natural compounds for effective and reduce the effects.

Coffee one of the cultivation in Indonesia. Coffee has natural compounds, caffeic acid has functions inhibitor COX-2 (Bare et al., 2019a) and chlorogenic acid. Chlorogenic acid is one of the chemicals compounds in coffee beans (Moon et al., 2009; Watanabe et al., 2006). Shi et al., (2013) reported chlorogenic acid has potentially associated with various inflammatory response inhibition by in vitro study in case of reduces liver inflammation and fibrosis. Bare et al., (2019b) reported chlorogenic acid has a function to inhibit ACE. Using the chlorogenic acid expected to reduce toxicity and side effects to human body. In this paper, we analyze and investigate the potential of chlorogenic acid as anti-inflammatory agents by inhibiting COX-2 roles used in silico approach.

\section{MATERIALS AND METHODS}

Ligand and Protein Preparation. Protein Data Bank (PDB) from www.rscb.org was used to acquire a database to get 3D COX-2 with ID: 6cox (Kurumbail et al., 1996), while the chemical structure of chlorogenic acid (CID: 1794427) was acquired from the database of PubChem.com. Minimalizing energy chlorogenic acid by open babel in PyRx Virtual screening tool. Removing ligand from water molecules used Discovery Studio Client 4.1. Converting ligand from SDF format file to PDB file using PyRx Virtual screening tool software. Preparation COX-2 by removing ligand that binding with protein using Discovery Studio Client 4.1.

Molecular Docking. Ligand chlorogenic acid was docked with protein $\mathrm{COX}-2$ by in silico. Molecular docking was established using Hex 8.0.0 version software. Then ligand and protein that docked in HEX, we visualize and analyze the molecular interactions of chlorogenic acid and COX-2 by Discovery Studio client 4.1 software. The analyzation including amino acid resides, hydrogen bonds, van der Waals and energy binding which formed by the interactions.

\section{RESULT AND DISCUSSION}

The chlorogenic acid and COX-2 interactions were shown the binding of amino acid residues with chlorogenic acid. The types of chemistry bond, which formed between ligand, and amino acid residues are hydrogen bonds. Interactions between ligand and protein showed fifteen amino acid residues which correlating with the chlorogenic acid in B domain. The amino acid residues are HIS207, PHE210, LYS211, THR212, ASP213, HIS214, LYS215, ARG216, ARG222, ILE274, GLN289, GLU290, VAL291, ASN382, HIS386 The bond that occurs in amino acid residues LYS215, GLU290, ASN382 is hydrogen bond type conventional hydrogen bond while HIS207 is hydrophobic. Binding between ligand-protein had the energy binding $-327.59 \mathrm{cal} / \mathrm{mol}$.

Farah et al. (2008) reported chlorogenic acid which consumed by the human has highly bioavailable in humans. Chlorogenic acid has molecular weight $354.311<500$, the value of the $\log$ coefficient of octanol/water $(\log \mathrm{P})$ $0.6459>5$, H-receptor (HBA) under 8 and the donor H-bond (HBD) 6>5. Chlorogenic acid has been clear in humans' metabolism and kinetics, furthermore it has high permeability and is easily absorbed by the body based on Lipinski et al., (1997). In this research, we found hydrogen bond, binding chlorogenic 
acid, and LYS215, GLU290, and ASN382. This interaction of those causes the disorientation of the substrate. In amino residue, HIS207 formed hydrophobic interactions, which affect the substrate and nucleophile orientation. The distance in hydrogen bond that formed in amino acid residue LYS215 smaller than amino acid residues GLU290 and ASN382 has an effect on the strength of the bond. The smaller distance of hydrogen to the acceptor leads, the bond will be stronger (Santoso et al., 2016).
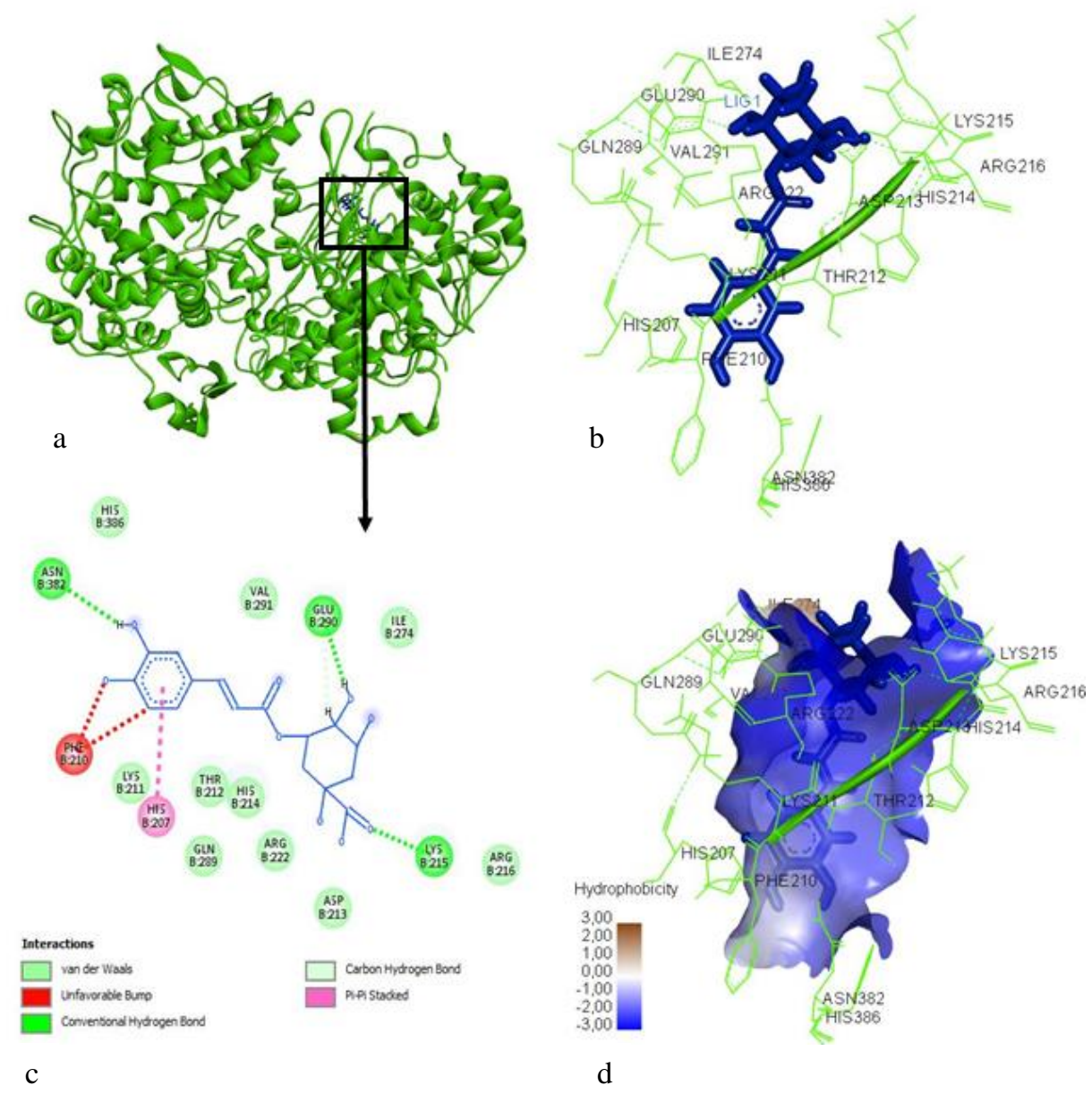

Figure 1. Molecular interaction between chlorogenic acid and COX-2: a. Ligand and protein interactions; b. 3D structure interaction. Interactions Van der Waals, unfavorable bump, conventional hydrogen bond, carbon-hydrogen bond, and Pi-Pi stacked; c. 2D structure interaction; d. Hydrophobicity complex

The chlorogenic acid has an affinity with the activator side of COX-2 in amino acid residues, which bind with a hydrogen bond. The inflammation pathway was role by COX-2 such as PI3K, NF- $\kappa \beta$, and Akt was blocked when chlorogenic acid deactivated COX-2 by interaction on (active side domain of COX-2) (Rachmad et al., 2018).

Table 1. Interaction chlorogenic acid and COX-2 protein

\begin{tabular}{|c|c|c|c|c|c|c|c|}
\hline Complexes & $\begin{array}{l}\text { Energy } \\
\text { (cal/mol) }\end{array}$ & Name & Distance & Category & Types & $\begin{array}{c}\text { from } \\
\text { chemistry }\end{array}$ & $\begin{array}{c}\text { to } \\
\text { chemistry }\end{array}$ \\
\hline \multirow[t]{2}{*}{$\begin{array}{l}\text { Chlorogenic } \\
\text { acid-COX-2 }\end{array}$} & \multirow[t]{2}{*}{-327.59} & $\begin{array}{l}\text { B:LYS215:HN - } \\
\text { :LIG1:O }\end{array}$ & 1.78522 & $\begin{array}{l}\text { Hydrogen } \\
\text { Bond }\end{array}$ & $\begin{array}{l}\text { Conventional } \\
\text { Hydrogen } \\
\text { Bond }\end{array}$ & H-Donor & H-Acceptor \\
\hline & & $\begin{array}{l}\text { :LIG1:H } \\
\text { B:GLU290:OE1 }\end{array}$ & 2.48003 & $\begin{array}{l}\text { Hydrogen } \\
\text { Bond }\end{array}$ & $\begin{array}{l}\text { Conventional } \\
\text { Hydrogen } \\
\text { Bond }\end{array}$ & H-Donor & H-Acceptor \\
\hline
\end{tabular}




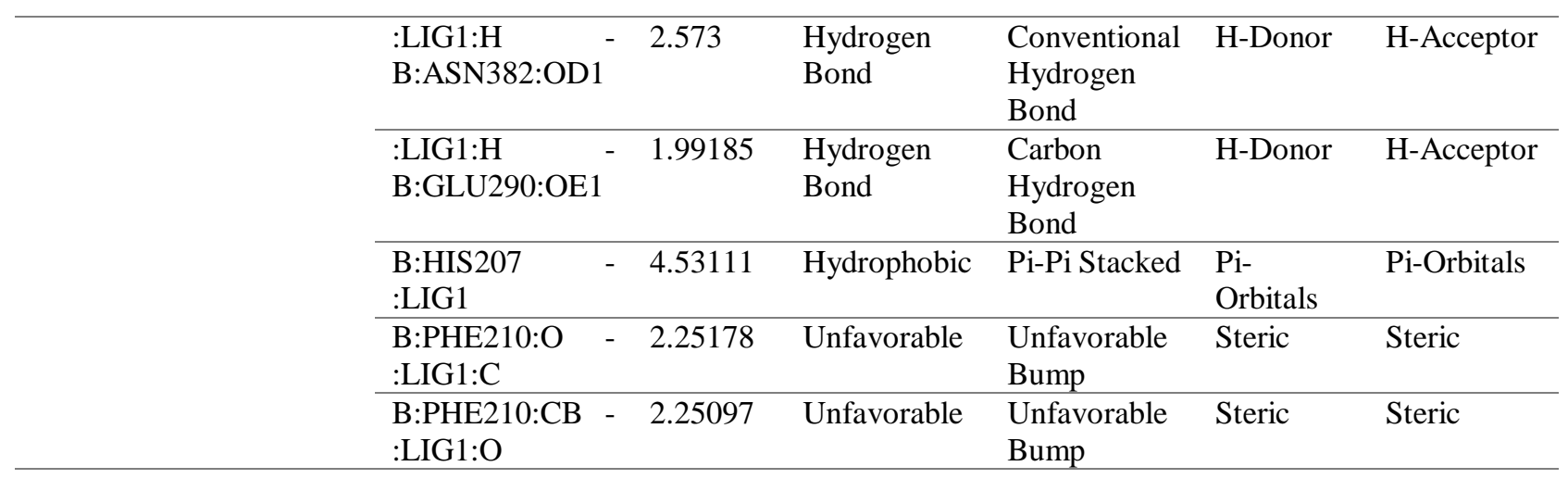

COX-2 is a central enzyme in the biosynthesis of prostaglandins. These activated by inflammatory inducements, such as cytokines and lipopolysaccharide. In the cell metabolic pathway, COX-2 was induced by prostaglandin production implicated to increase inflammation, matrix tissue remodeling, fibrosis progress and expansion of tumor genesis (Shi et al., 2013).

Recently study shown that Ser-530 was homolog in COX-1 and COX-2 indicated that NSAID was non-selected inhibitors for COX-2 (Smith \& Murphy, 2016). Interestingly, our study found another active site that binds chlorogenic acid. Chlorogenic acid has activity to induce inactivation of $\mathrm{COX}-2$ by the interactions in amino acid residues LYS215, GLU290, ASN382 and HIS207.

Compare to affinity character between chlorogenic acid and COX-2 in this research indicated that interaction was blocking at $\mathrm{COX}$ 2 in different active site location compare to other ligand complexes COX-2 NSAID (Perez et al., 2019). Different binding sides in COX-2 have potential role for inhibiting COX-2 function in different effects compare to chemical drugs.

Interaction leads effectively to reduce chronic inflammation that indicated to pathophysiological damage. This mechanism has been extensively shown in preclinical and epidemiological studies that support the targeting of the COX-2 pathway for the prevention and treatment of malignancy. In another study, the blocked activity of COX-2 and upregulating of PGE2 synthase have prevalent roles to inhibit and reducing cancer factors progression. Inactivation $\mathrm{COX}-2$ can down-regulated these effects through several signaling pathways such as stimulation of vascular endothelial growth factor (VEGF) leading to increased cell proliferation, metastatic endothelial and angiogenesis (Xu et al., 2014). Another effect can lead to upregulating the protooncogenes, BCL-2, and the epidermal growth factor receptor (EGFR), were mediated by the initiation of the mitogenactivated protein kinase (MAPK) and the phosphoinositide 3-kinase (PI3K)/AKT pathway, respectively (Buchanan et al., 2003). In some cases, increased transcriptional activity of the anti-apoptotic mediator nuclear factor- $\kappa \mathrm{B}$ (NF-kB) (Poligone \& Baldwin, 2001).

Inactivated COX-2 protein expression in target tissue, Pop-Busui et al. (2008) showed that inactivation gen of COX-2 in diabetic mice with COX-2 specific inhibition in diabetic rats prevented nerve conduction deficits. In this case, diabetes encouraged production-specific biomarkers by oxidative stress and inflammation. Systematical effect with potential to progression of PG and correlated with imbalance in the peripheral nerves. In another result also shown that COX-2 gene inactivation protects against diabetes-induced damage in some targeted tissue (Rachmad et al., 2018).

\section{CONCLUSION}

Based on interaction model, Chlorogenic acid has potential role as therapeutic agent antiinflammation by inhibiting cyclooxygenase- 2 . The interactions between ligand and protein formed fifteen amino acid residues, which interacted with chlorogenic acid. Besides that, we found type of interactions such as hydrogen bonds, van der Waals, hydrophobic with the energy binding-327.59cal $/ \mathrm{mol}$. Inhibiting 
COX-2 might correlated with oxidative and derivate of prostaglandins compound but need further study to prove the efficacy of chlorogenic acid.

\section{REFERENCES}

Abdulkhaleq LA, Assi MA, Abdullah R, Zamri-Saad M, Taufiq-Yap YH, Hezmee MNM. 2018. The crucial roles of inflammatory mediators in inflammation: a review. Vet World. vol 11: 627-635. https://doi.org/10.14202/vetworld.2018.62 7-635.

Al-Saeed A. 2011. Gastrointestinal and cardiovascular risk of nonsteroidalantiinflammatory drugs. Oman Medical Journal. 26, 385-391. doi: https://doi.org/10.5001/omj.2011.101.

Bäck M, Yin L, Ingelsson E. 2012. Cyclooxygenase-2 inhibitors and cardiovascular risk in a nation-wide cohort study after the withdrawal of rofecoxib. European Heart Journal. vol 33(15): 1928-1933.

https://doi.org/10.1093/eurheartj/ehr421.

Bare Y, Krisnamurti GC, Elizabeth A, Rachmad YT, Sari DRT, Lorenza MRWG. 2019a. The potential role of caffeic acid in coffee as cyclooxygenase-2 (COX-2) inhibitor: in silico study. Biointerface Research Applied Chemistry. vol 9(5): 4424-4427.

doi: https://doi.org/10.33263/BRIAC95.42442 7.

Bare Y, Marhendra A, Sasase T, Fatchiyah F. 2018. Differential expression of IL-10 gene and protein in target tissues of Rattus norvegicus strain wistar model type 2 diabetes mellitus (T2DM). Acta Informatica Medica. vol 26(2): 87-92. doi: https://doi.org/10.5455/aim.2018.26.8792.

Bare Y, Sari DRT, Rachmad YT, Sulistyaningsih S, Tiring ND, Rophi AH, Nugraha FAD. 2019b. Prediction potential chlorogenic acid as inhibitor ace (in silico study). Bioscience. vol 3(2): 197-203. doi: https://doi.org/10.24036/02019321058560-00.
Buchanan FG, Wang D, Bargiacchi F, DuBois RN. 2003. Prostaglandin $E_{2}$ regulates cell migration via the intracellular activation of the epidermal growth factor receptor. Journal Biological Chemistry. vol 278(3): 35451-35457.

doi: https://doi.org/10.1074/jbc.M302474200.

Farah A, Monteiro M, Donangelo CM, Lafay S. 2008. Chlorogenic acids from green coffee extract are highly bioavailable in humans. The Journal of Nutrition. vol 138(12): 2309-2315. doi: https://doi.org/10.3945/jn.108.095554.

Knights KM, Mangoni AA, Miners JO. 2010. Defining the COX inhibitor selectivity of NSAIDs: implications for understanding toxicity. Expert Revie Clinical Pharmacology. vol 3(6): 769-776. doi: https://doi.org/10.1586/ecp.10.120.

Kurumbail RG, Stevens AM, Gierse JK, McDonald JJ, Stegeman RA, Pak JY, Gildehaus D, Miyashiro JM, Penning TD, Seibert K, Isakson PC, Stallings WC., 1996. Structural basis for selective inhibition of cyclooxygenase- 2 by antiinflammatory agents. Nature. vol 384(6610): 644-648. doi: https://doi.org/10.1038/384644a0.

Lipinski CA, Lombardo F, Dominy BW, Feeney PJ. 1997. Experimental and computational approaches to estimate solubility and permeability in drug discovery and development settings. Advanced Drug Delivery Reviews. vol 46(1-3): 3-26. doi: https://doi.org/10.1016/S0169409X(96)00423-1.

Moon JK, Yoo HS, Shibamoto T. 2009. Role of roasting conditions in the level of chlorogenic acid content in coffee beans: correlation with coffee acidity. Journal of agricultural and food chemistry. vol 57(12): 5365-5369. doi: https://doi.org/10.1021/jf900012b.

Perez YR, Alvarez D, Combariza A. 2019. Ligand-Protein Interactions: A Hybrid ab initio/Molecular

Mechanics Computational Study. Preprints. vol 1(2019): 1-24. doi: 
https://doi.org/10.20944/preprints201902. 0124.v1.

Phalitakul S, Okada M, Hara Y, Yamawaki H. 2011. Vaspin prevents TNF- $\alpha$-induced intracellular adhesion molecule-1 via inhibiting reactive oxygen speciesdependent $\mathrm{NF}-\kappa \mathrm{B}$ and $\mathrm{PKC} \theta$ activation in cultured rat vascular smooth muscle cells. Pharmacological Research. vol 64(5): 493-500. doi: https://doi.org/10.1016/j.phrs.2011.06.001

Poligone B, and Baldwin AS. 2001. Positive and negative regulation of NF- $\kappa \mathrm{B}$ by COX2: roles of different prostaglandins. The Journal of Biological Chemistry. vol 276(42): 38658-38664. doi: https://doi.org/10.1074/jbc.M106599200.

Pop-Busui R, Kellogg A, Cheng H. 2008. Cyclooxygenase-2 Pathway as a Potential Therapeutic Target in Diabetic Peripheral Neuropathy. Current Drug Targets. vol 9(1): 68-76. doi: https://doi.org/10.2174/138945008783431 691.

Rachmad, Y.T., Wihastuti, T.A., Miyajima, K., Fatchiyah, F., 2018. Activity of caprine CSN1S2 protein reducing the COX-2 and IL-17 expression of aorta tissue in type 2 diabetes mellitus rat. Journal of Mathematical and Fundamental Sciences. vol 50(3): 332-345. doi: https://doi.org/10.5614/j.math.fund.sci.20 18.50.3.8.

Santoso B, Atmajaya TE, Tirtodiharjo MK. 2016. Kajian docking senyawa $4-[(\mathrm{Z})-\mathrm{N}-$ (4-hidroksifenil) carboksimidoil]-2metoksifenol sebagai inhibitor Cox-2 menggunakan plants. Prosiding Seminar
Nasional Kimia UNJANI-HKI. 3-4 Agustus 2016. Bandung: Universitas Jenderal Achmad Yani. ISBN 978-60260732-0-4. pp. 270-275.

Shi H, Dong L, Jiang J, Zhao J, Zhao G, Dang X, Lu X, Jia M. 2013. Chlorogenic acid reduces liver inflammation and fibrosis through inhibition of toll-like receptor 4 signaling pathway. Toxicology. vol 303: 107-114. doi: https://doi.org/10.1016/j.tox.2012.10.025.

Smith WL, and Murphy RC. 2016. The Eicosanoids: Cyclooxygenase, Lipoxygenase and Epoxygenase Pathways in: Biochemistry of Lipids, Lipoproteins and Membranes. Amsterdam: Elsevier. pp. 259-296. doi: https://doi.org/10.1016/B978-0-44463438-2.00009-2.

Watanabe T, Arai Y, Mitsui Y, Kusaura T, Okawa W, Kajihara Y, Saito I. 2006. The blood pressure-lowering effect and safety of chlorogenic acid from green coffee bean extract in essential hypertension. Clinical and experimental hypertension. vol 28(5): 439-449.

doi: https://doi.org/10.1080/106419606007986 55.

Xu L, Stevens J, Hilton MB, Seaman S, Conrads TP, Veenstra TD, Logsdon D, Morris H, Swing DA, Patel NL, Kalen J, Haines DC, Zudaire E, St. Croix B. 2014. COX-2 inhibition potentiates antiangiogenic cancer therapy and prevents metastasis in preclinical models. Science Translational Medicine. vol 6(242): 242ra84-242ra84. doi: https://doi.org/10.1126/scitranslmed.3008 455. 